\title{
A re-institucionalização da Igreja Estudo teológico-pastoral sobre o da plausibilidade eclesial na cultura atual
}

\author{
Orientador: Abimar Oliveira de Moraes \\ Doutoranda: Arlene Denise Bacarji \\ Área de Concentração: Teologia Sistemático-Pastoral \\ Linha de Pesquisa: Fé e Cultura
}

A presente pesquisa trata da crise que a Igreja enfrenta na cultura atual, tanto no âmbito de relações externas como internas a esta instituição. No âmbito externo trata-se da morte das instituições, silêncio das massas, emergência do sujeito e crise de sentido; no âmbito interno trata-se de dificuldades em se relacionar com estas características da cultura atual que quebram a plausibilidade da instituição Igreja perante a sociedade. Para tanto, foram necessários aportes doutrinários, sociológicos e teológicos no que diz respeito ao processo de institucionalização e à relação deste com a formação de sentido, como sobre o processo de institucionalização da Igreja e formação de sentido dentro dela, respectivamente. Em uma perspectiva trans e interdisciplinar, este trabalho é teológico-pastoral e oferece pistas de ações pastorais que possam sugerir modos de proceder que venham a contribuir para uma Igreja que cumpra melhor sua missão evangelizadora por meio do sensus fidei, que é uma categoria única que contempla a emergência do sujeito na cultura atual, re-significando a vida da Igreja, e esta, a vida das pessoas, e assim re-institucionalizando-a.

Palavras-chave: Instituição, sentido, cultura atual. 